\title{
AGROSILVOPASTURA SEBAGAI SISTEM PERTANIAN TERENCANA MENUJU PERTANIAN BERKELANJUTAN
}

\author{
(AGROSILVOPASTURAI AS PLANNED FARMING SYSTEMS TOWARDS \\ SUSTAINABLE AGRICULTURE)
}

\author{
Amar Ma'ruf
}

Universitas Asahan

\begin{abstract}
ABSTRAK
Agroforestri juga sebagai model pertanian berkelanjutan. Sistem agroforestri terbentuk atas tiga komponen pokok yaitu perhutanan, pertanian, peternakan. Sistem agrosilvopastura adalah pengombinasian komponen berkayu (kehutanan) dengan pertanian (semusim) dan sekaligus peternakan/binatang pada unit manajemen lahan yang sama.Urutan prioritas alternatif pilihan terpenting untuk pertanian berkelanjutan antara lain penguatan kelembagaan petani, mengembangkan pengkaderan petani/kelompok tani sadar pertanian berkelanjutan, dan peningkatan kegiatan demplot teknologi pertanian berkelanjutan. Analisis finansial menunjukkan bahwa secara ekonomi semua sistem agroforestri, dan agrosilvopastura yang paling banyak memberikan input dibanding agrosilnikultur dan silvopastura. Erosi yang terjadi pada lahan agroforestri, terutama agrosilvokultura di kawasan penyangga Kabuaten Langkat tidak membahayakan karena lebih kecil dari erosi yang diperbolehkan ( $<31,6$ ton/ha/thn). Total biomassa dan karbon tegakan pada sistem agroforestri dengan tipeagrosilvopastura masingmasing sebesar 104.17 dan 46.74 ton per hektar hampir sama dengan total biomassa dan karbon total tegakan pada hutan mangrove Rhizophora apiculata dengan kerapatan 463 pohon per hektar yang masing-masing sebesar 169.46 (biomassa) dan 47.08 (karbon) ton per hektar. Sistem agrosilvopastura dapat berperan dalam memitigasi banjir dibandingkan pada sistem pertanian monokultur untuk setiap hektar lahan pada setiap 1 jam kejadian hujan.
\end{abstract}

Key word: agrosilvopastura, agroforestri, berkelanjutan

\section{PENDAHULUAN}

Bank Dunia menerjemahkanparadigma pembangunan berkelanjutan dalam bentuk kerangka segitiga pembangunan berkelanjutan (Environmentally Sustainable Development Triangle).Pembangunan berkelanjutan bertumpu padakeberlanjutan ekonomi, ekologi, dan sosial. Berkelanjutan secara ekonomis adalah suatu kegiatan pembangunan harus mampu menghasilkan pertumbuhan ekonomi, pemeliharaan kapital, penggunaan sumberdaya, serta investasi secara efisien. Berkelanjutan secara ekologis berarti bahwa kegiatan tersebut mampu mempertahankan integritas ekosistem, memelihara daya dukung lingkungan, dan konservasi sumberdaya alam termasuk keanekaragaman hayati (biodiversity). Keberlanjutan secara sosial berarti bahwa pembangunan tersebut dapat menciptakan pemerataan hasil-hasil pembangunan, mobilitas sosial, kohesi sosial, partisipasi masyarakat, pemberdayaan masyarakat, identitas sosial, dan pengembangan kelembagaan (Serageldin, 1996 dalam Dahuri 1998).

Pertanian berkelanjutan mempunyai beberapa prinsip yaitu: (a) menggunakan sistem input luar yang efektif,produktif, murah, dan membuang metode produksi yangmenggunakan sistem input dari industri, (b) memahami dan menghargai kearifan lokal serta lebih banyak melibatkan peran petani dalam pengelolaan sumberdaya alam dan pertanian, (c) melaksanakan konservasi sumberdaya alam yang digunakan dalam sistem produksi (Shepherd, 1998 dalam 
Budiasa, 2011). Persoalan yang sering dihadapi dalam mewujudkan pertanian berkelanjutan adalah adanya tarik-menarik antar berbagai kepentingan pembangunan. Beberapa faktor yang mempengaruhi keberhasilan pertanian berkelanjutan antara lain faktor sosial, ekonomi, dan kelembagaan (Purwanto dan Cahyono, 2012); faktor pilihan teknis konservasi yang tepat, sesuai dengan latar belakang sosial, ekonomi, budaya masyarakat (Sabiham dalam Arsyad, S. dan E. Rustiadi, 2008); faktor individu, ekonomi, dan kelembagaan (Illkpitiya dan Gopalakrishnan, 2003); faktor kelembagaan, kebijakan pemerintah, dan perubahan teknologi (Ananda dan Herath, 2003). Upaya untuk menyelaraskan berbagai aspek kepentingan dengan tetap menjaga kelestarian lingkungan merupakan tantangan dalam mewujudkan pembangunan pertanian berkelanjutan.

Menurut Salikin (2003), bahwa sistem pertanian berkelanjutan dapat dilaksanakan menggunakan berbagaimodel antara lain sistem pertanian organik, integrated farming, pengendalian hama terpadu, dan LEISA (LowExternal Input Sustainable Agriculture). Sistem pertanian organik merupakan sistem produksi pertanian yangmenjadikan bahan organik sebagai faktor utama dalam proses produksi usahatani. LEISA (low-external-input and sustainable agriculture) adalah pertanian yang mengoptimalkan pemanfaatan sumberdaya alam dan manusia setempat/lokal, layak secara ekonomis, mantap secara ekologis, sesuai dengan budaya, adil secara sosial, dan input luar hanya sebagai pelengkap (Reijntjes et al. 1999). Integrated pest management atau pengelolaan hama terpadu merupakan suatu teknologi pengendalian hama yang bertujuan untuk memaksimalkan efektivitas pengendalian secara biologi dan budaya. Pengendalian secara kimia dilakukan dengan meminimalkan gangguan terhadap lingkungan (Luna dan House, 1990 dalam Budiasa, 2011). Sementara itu, agroforestri juga sebagai model pertanian berkelanjutan. Sistem agroforestri terbentuk atas tiga komponen pokok yaitu perhutanan, pertanian, peternakan. Kombinasi komponen-komponen tersebut menghasilkan bentuk agrisilvikultur (perhutanan + pertanian), silvopastura (perhutanan + peternakan), dan agrosilvopastura (perhutanan+ pertanian + peternakan) (Budiasa, 2011). Gambaran yang menunjukkan ruang lingkup sistem pemanfaatan lahan secara agroforestridapat dilihat pada gambar 1. Sistem usahatani konservasi merupakan integrasi dari kegiatan usahatanidan kegiatan konservasi yang dilakukan pada lahan berlereng (Idjudin, 2011). Pengendalian erosi tanah, konservasiair, peningkatan produktivitas tanah, dan stabilitas lereng perbukitan merupakan prinsip-prinsip usahatani konservasi (Idjudin et al. 2003). Sistem penanaman ganda (multiple cropping system) bertujuan untuk memperkecil risiko usahatani sekaligus berfungsi dalam pengelolaan hama terpadu, dan pemeliharaan kesuburan ranah (Budiasa, 2011).Sedangkan fungsi penghasil jasa yang tidak tampak nyata dari sistem agroforestri antara lain adalah menyeimbangkan kualitas lingkungan seperti memitigasi banjir, pengendali erosi tanah, pemelihara pasokan air tanah, penambat karbon, penyejuk dan penyegar udara, dan pemelihara keanekaragaman hayati), serta menciptakan panorama (keindahan) dan daya tarik pedesaan (Nair, 1989c; Chundawat and Gautam, 1993; Lal, 1995).

\section{Agrosilvopastura (Agrosilvopastural systems)}

Sistem agrosilvopastura adalahpengombinasian komponen berkayu (kehutanan) dengan pertanian (semusim)dan sekaligus peternakan/binatang pada unit manajemen lahan yang sama.Tegakan hutan alam bukan merupakan sistem agrosilvopastura, walaupunketiga komponen pendukungnya juga bisa dijumpai dalam ekosistemyang dimaksud. Pengombinasian dalam agrosilvopastura dilakukan secaraterencana untuk mengoptimalkan fungsi produksi dan jasa (khususnyakomponen berkayu/kehutanan) kepada manusia/masyarakat (to serve people).Tidak tertutup kemungkinan bahwa kombinasi juga didukung olehpermudaan alam dan satwa liar. Interaksi komponen agroforestri secara alami mudahdiidentifikasi. Interaksi paling sederhana sebagai contoh adalah peranantegakan sebagai penyedia pakan satwa liar (misal buah-buahan untuk berbagaijenis burung), dan sebaliknya misalnya fungsi satwa liar dapat 
membantu proses penyerbukan atauregenerasi tegakan, serta sumber protein hewani bagi petani(Anonim).

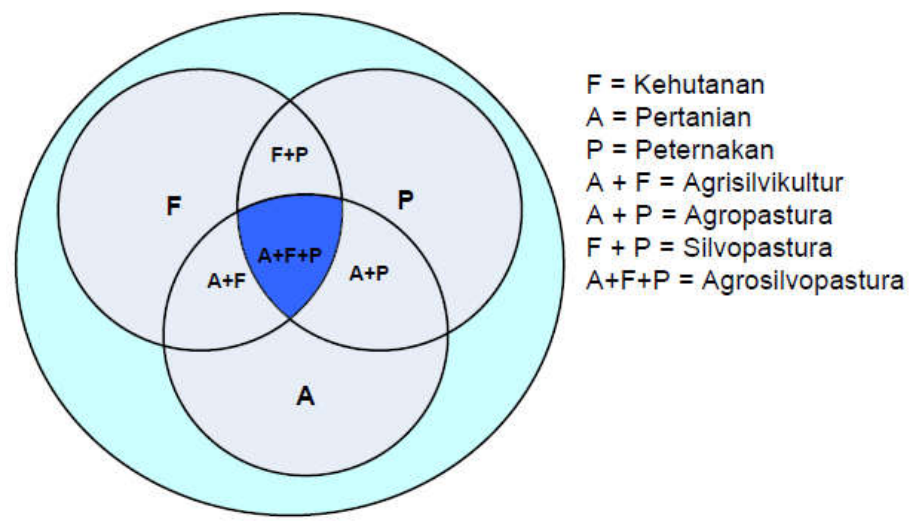

\section{Gambar 1. Ruang Lingkup Sistem Pemanfaatan Lahan Secara Agroforestri Sumber: Anonim}

\section{PEMBAHASAN}

\section{Kriteria dan Alternatif Untuk Penelusuran Aspek Sosial Pertanian Berkelanjutan}

Untuk parameter mengenai aspek sosial, terdapat data penelusuran pertanian berkelanjutan yang dilakukan di Kecamatan Selo, Kabupaten Boyolali, Jawa Tengah. Berdasarkan hasil penelusuran pustaka dapat diketahui bahwa beberapa kriteria yang mempengaruhikeberhasilan pertanian berkelanjutan antara lain: sosial budaya, ekonomi, teknologi pertanian, kelembagaan, dankebijakan pemerintah. Penyusunan perencanaan pertanian berkelanjutan di Kecamatan Selo dapat dilihat pada gambar 2.

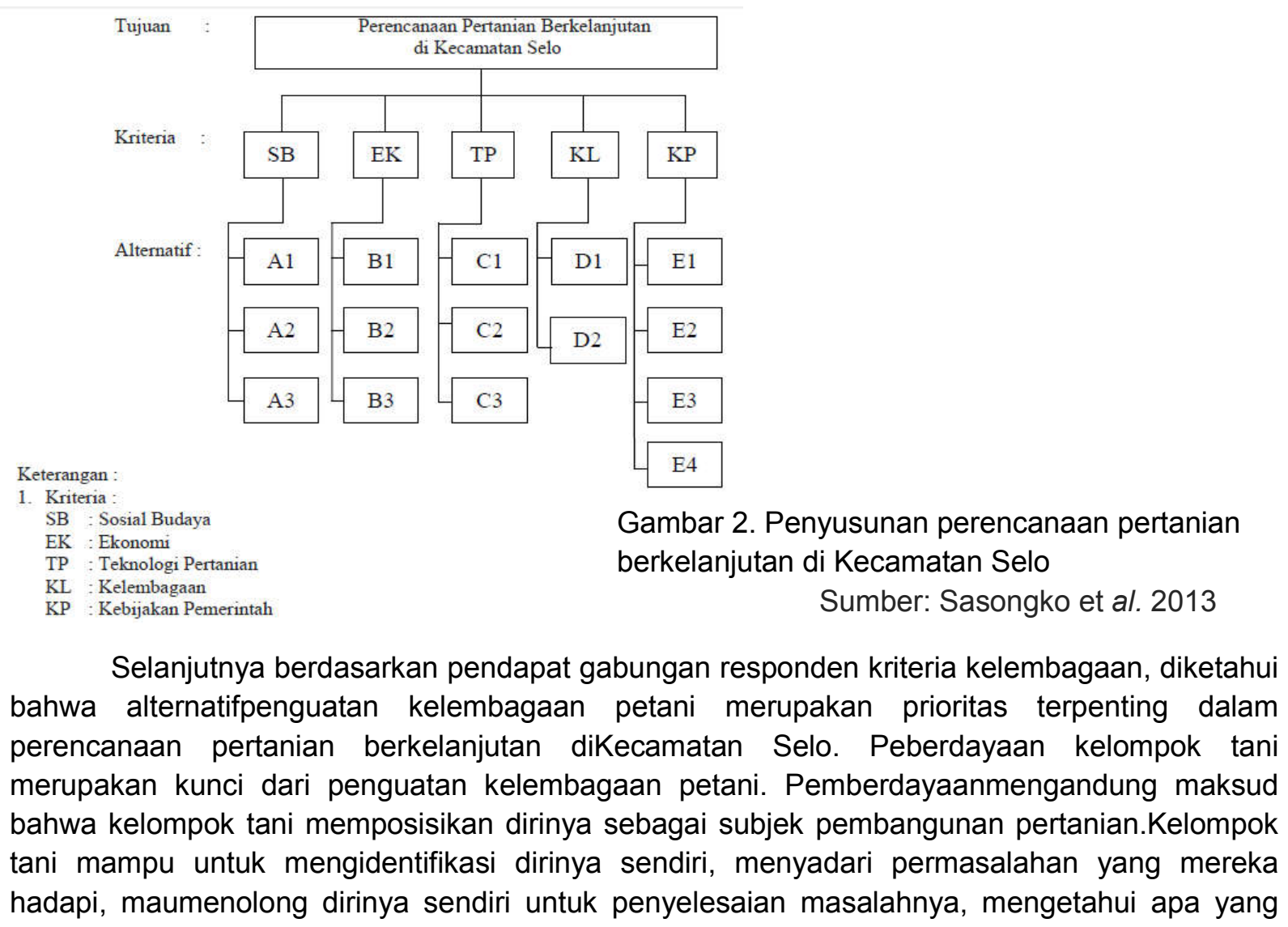


sebenarnya menjadi kebutuhankelompok, dan akhirnya meningkatkan peran kelompok tani secara mandiri. Kecenderungan sebagian kelompok tani yang ada belum optimal fungsi dan pengelolaannya. Hal tersebut karena sebagian kelompok tani lebihmemposisikan diri sebagai objek dari program/kegiatan pembangunan pertanian, yaitu wadah penerima bantuanbaik dari pemerintah maupun penyandang dana lainnya. Kelembagaan petani lebih cenderung bersifatketergantungan dimana aktif atau tidaknya peran dan fungsi kelembagaan bergantung kepada ada tidaknya bantuanyang diberikan.

Tabel 1. Hasil sintesis pembobotan seluruh alternatif menunjukkan urutan prioritas

\begin{tabular}{|c|c|c|}
\hline Kode & Nilai (\%) & Uraian \\
\hline D1 & 9,0 & Penguatan kelembagaan petani. \\
\hline A2 & 8,9 & $\begin{array}{l}\text { Mengembangkan pengkaderan petani / kelompok tani sadar pertanian } \\
\text { berkelanjutan. }\end{array}$ \\
\hline $\mathrm{C} 2$ & 8,8 & Peningkatan kegiatan demplot teknologi pertanian berkelanjutan. \\
\hline C1 & 8,3 & Peningkatan akses informasi dan transfer teknologi pertanian \\
\hline B1 & 8,2 & berkelanjutan. \\
\hline & & Perubahan pola bertani menuju agribisnis. \\
\hline A1 & 7,8 & Peningkatan kualitas SDM petani. \\
\hline $\mathrm{D} 2$ & 6,7 & $\begin{array}{l}\text { Meningkatkan peran penyuluh dalam rangka pembinaan terhadap } \\
\text { kelembagaan petani. }\end{array}$ \\
\hline E1 & 6,4 & $\begin{array}{l}\text { Insentif bagi petani yang mau dan mampu menerapkan sistem pertanian } \\
\text { berkelanjutan. }\end{array}$ \\
\hline B3 & 5,9 & Meningkatkan dukungan permodalan usahatani. \\
\hline C3 & 5,6 & $\begin{array}{l}\text { Pengembangan integrasi tanaman semusim, tanaman tahunan bernilai } \\
\text { tinggi, ternak. }\end{array}$ \\
\hline A3 & 5,5 & Mengembangkan nilai - nilai kearifan lokal tentang pelestarian alam. \\
\hline B2 & 5,4 & Mewujudkan alternatif sumber ekonomi selain pertanian on farm. \\
\hline E4 & 4,9 & Pengawalan kegiatan pertanian berkelanjutan. \\
\hline E2 & 4,6 & Pembuatan, penegakan regulasi berkaitan dengan tata guna lahan. \\
\hline E3 & 4,0 & $\begin{array}{l}\text { Memasukkan pelajaran tentang pelestarian lingkungan spesifik lokasi } \\
\text { dalam kurikulum pendidikan formal mulai dari tingkat dasar. }\end{array}$ \\
\hline
\end{tabular}

Sumber: Sasongko et al. 2013

Melalui program/kegiatan pemberdayaan kelembagaan petani diharapkan para petani mampumengambil inisiatif secara mandiri untuk menyelesaikan permasalahan yang dihadapi khususnya berkaitan denganpenerapan pertanian berkelanjutan. Bantuan dari berbagai pihak yang diberikan benar-benar dirasakan sebagaikebutuhan kelompok dan bagian dari perencanaan mereka untuk mengatasi permasalahan yang dihadapi. Haltersebut akan menjamin keberlangsungan bantuan/kegiatan yang diberikan karena memang dibutuhkan danterdapat rasa memiliki oleh para petani. Selain itu kelembagaan petani penting untuk meningkatkan perannya dalammenjalin kerjasama saling menguntungkan dengan berbagai pihak dalam rangka mengatasi permasalahan yangdihadapi, misalnya harga rendah ketika terjadi over produksi diatasi dengan sistem kemitraan (Sasongko et al. 2013)

Prioritas alternatif berikutnya adalah mengembangkan pengkaderan kelompok tani/petani sadar pertanian berkelanjutan sebagai pioneer/contoh/teladan. Program/kegiatan tersebut menjadi cukup penting dan strategis karena petani memerlukan sosok, figur, contoh, teladan yang berhasil telah menerapkan model pertanian berkelanjutan. Melalui proses tersebut petani akan melihat secara langsung, belajar, menganalisa, mempertimbangkan, dan akhirnya memutuskan. Pengenalan bentuk-bentuk penerapan pertanian berkelanjutan melalui contoh 
nyata akan lebih mudah diterima dibandingkan dengan teori di dalam ruangan. Kader-kader petani/kelompok tani perlu terus dirintis oleh berbagai pihak, agar semakin tumbuh subur para pelaku model-modelpertanian berkelanjutan sehingga para petani lain tidak kesulitan meniru, mencontoh, praktek-praktek pertanianyang menerapkan prinsip-prinsip pertanian berkelanjutan di sekitar mereka (Sasongko et al. 2013)

Prioritas alternatif selanjutnya adalah peningkatan demplot teknologi pertanian berkelanjutan. Demplotmenjadi penting untuk memperkenalkan teknologi pertanian berkelanjutan yang ada, bagaimana operasionalisasinya, hasil/keuntungannya, kemudian para petani menjadi mengetahui, yakin, dan percaya terhadapteknologi pertanian yang diintroduksikan. Harapannya agar terjadi proses perubahan/peningkatan pengetahuan,sikap, dan perilaku petani dalam penerapan pertanian berkelajutan (Sasongko et al. 2013)

\section{Keseuaian Lahan dan Aspek Ekonomi pada Agrosilvopastura}

Pada review makalah ini, analisis finansial terhadap sistem agroforestri dilakukan di Kecamatan Indrapuri, Kabupaten Aceh Besar dengan jangka waktu pengusahaan 20 tahun dan tingkat suku bunga $8 \%$, di peroleh, nilai NPV $>0$ (positif), dan B/C Ratio $\geq 1$ dan nilai IRR $\geq$ tingkat suku bunga (i) untuk semua bentuk penggunaan lahan, dapat dilihat pada tabel 2. Dari data tersebut menunjukkan bahwa semua sistem agroforestri baik yang berbentuk agrisilvikultur, silvopastura maupun agrisilvopastura layak untuk dilaksanakan.Untuk mengamati kesesuaian lahan, yakni dengan melihat komponen-komponen agrosilvopastura yang dapat dilihat pada tabel 3.

Tabel 2. Analisis finansial agroforestri per hektar di Kecamatan Indrapuri

\begin{tabular}{|l|l|l|l|}
\hline Kriteria & Agrisilvikultur & Silvopastura & Agrisilvopastura \\
\hline NPV & Rp. 55.374.410,- & Rp.84.111.784,- & Rp.147.896.794,- \\
BCR & 2,2 & 1,5 & 2,7 \\
IRR & $31 \%$ & $38 \%$ & $46 \%$ \\
\hline
\end{tabular}

Sumber: Bukhari dan Indra, 2009

Sistem silvopastura diperoleh hasil tingkat kesesuaian tanaman berkayu jati dan mahoni tergolong cukup sesuai (S2). Tanaman tahunan yaitu pisang tingkat kesesuaian lahan tergolong cukup sesuai (S2) dan untuk tanaman pakan ternak jenis rumput gajah memiliki tingkat kesesuaian lahan sesuai marjinal (S3). Hasil evaluasi kesesuaian lahan untuk jenis tanaman yang penggunaan lahannya berbentuk agrosilvopastura diperoleh hasil untuk komponen tanaman berkayu jati (Tectona grandis), mahoni(Swietennia sp), kemiri (Aleuritas moluccana), memiliki tingkat kesesuaian lahan tergolong cukup sesuai (S2); sedangkan mangga (Mangifera indica), nangka (Artocarpus integra), rambutan (Nephelium lappaceum), pinang (Areca catechu) memiliki tingkat kesesuaian lahan tergolong sesuai marjinal (S3). Selanjutnya tanaman tahunan pisang (Musa pudeca) dan kakao (Theobroma cacao $L$ ) dan pakan ternak rumput gajah (Pennisetum purpureum), memiliki tingkat kesesuaian lahan tergolong sesuai marjinal (S3).

Tabel 3. Komponen-komponen sistem agrosilvopastura di Kecamatan Indrapuri

\begin{tabular}{|l|l|l|l|}
\hline No. & \multicolumn{1}{|c|}{ Komponen } & \multicolumn{1}{|c|}{ Posisi } & \multicolumn{1}{c|}{ Tujuan } \\
\hline & Tanaman Berkayu & Punggung, lereng & Konservasi \\
1 & Mahoni (Swietennia sp) & Punggung, lereng & Konservasi \\
2 & Jati (Tectona grandis) & Lereng & Ekonomi/konservasi \\
3 & Kemiri (Aleuritas moluccana) & Lereng & Ekonomi/konservasi \\
4 & Mangga (Mangifera indica) & Lereng & Ekonomi/konservasi \\
5 & Nangka (Artocarpus integra) & Lereng, lembah & Ekonomi/konservasi \\
6 & Rambutan (Nephelium lappaceum) & Punggung, lereng & Ekonomi/konservasi \\
7 & Pinang (Areca catechu) &
\end{tabular}




\begin{tabular}{|c|c|c|c|}
\hline $\begin{array}{l}1 \\
2\end{array}$ & $\begin{array}{l}\text { Tanaman Tahunan } \\
\text { Pisang (Musa pudeca) } \\
\text { Kakao (Theobroma cacao L) }\end{array}$ & $\begin{array}{l}\text { Punggung, lereng } \\
\text { Lereng }\end{array}$ & $\begin{array}{l}\text { Ekonomi } \\
\text { Ekonomi }\end{array}$ \\
\hline $\begin{array}{l}1 \\
2\end{array}$ & $\begin{array}{l}\text { Tanaman Semusim } \\
\text { Cabai (Capsicum annum) } \\
\text { Terung (Solanum melongena) }\end{array}$ & $\begin{array}{l}\text { Lembah } \\
\text { Lembah }\end{array}$ & $\begin{array}{l}\text { Ekonomi } \\
\text { Ekonomi }\end{array}$ \\
\hline 1 & $\begin{array}{l}\text { Tanaman Pakan Ternak } \\
\text { Rumput Gajah (Pennisetum } \\
\text { purpureum) }\end{array}$ & Lereng, lembah & Ekonomi/konservasi \\
\hline $\begin{array}{l}1 \\
2\end{array}$ & $\begin{array}{l}\text { Ternak } \\
\text { Sapi (Bos taurus sp) } \\
\text { Itik (Anas plathyrhynchos) }\end{array}$ & $\begin{array}{l}\text { Punggung,lereng } \\
\text { Lembah }\end{array}$ & $\begin{array}{l}\text { Ekonomi } \\
\text { Ekonomi }\end{array}$ \\
\hline
\end{tabular}

Sumber: Bukhari dan Indra, 2009

Berdasarkan tingkat kesesuaian lahan, perlu juga dibuat desain agroforestri pada lahan kritis. Untuk mengadopsi teknologi kegiatan usaha tani perlu diketahui kendala spesifik yang ada di lokasi tersebut. Faktor penghambat itu sendiri, ada yang dapat dimanipulasi atau diperbaiki dengan teknologi, akan tetapi ada juga faktor penghambat yang sulit diperbaiki karena akan membutuhkan biaya yang tinggi dan sulit diperbaikioleh petani. Berdasarkan hasil evaluasi kesesuaian lahan maka direkomendasikan jenis tanaman berkayu Non MPTs adalah jati dan mahoni karena tergolong cukup sesuai (S2), untuk tanaman MPTsseperti rambutan, nangka, mangga, pinang dan kemiri pada daerah tertentu tergolong sesuai marginal (S3), akan tetapi dengan pemberian pupuk dapat ditingkatkan menjadi cukup sesuai (S2). Demikian juga halnya untuk tanaman tahunan seperti pisang dan kakao dengan pemberian pupuk dapat ditingkatkan kesesuaiannya menjadi cukup sesuai (S2). Untuk tanaman semusim seperti cabai, terung dan jagung, tergolong (S3) atau sesuai marginal, ini tentu saja membutuhkan input pupuk yang cukup tinggi dalam membudidayakannya.

Berdasarkan pengamatan dan wawancara, diperoleh profil komponen penyusun sistem agroforestri pada lahan kritis menurut landscape. Tanaman berkayuseperti jati dan mahoni akan lebih baik ditanampada daerah punggung bukit, karena lebih adaptifpada kondisi lahan yang ekstrim. Tanaman MPTs,tanaman tahunan dan pakan ternak lebih baikditanam pada bahagian lereng dan lembah,dengan asumsi bahwa tingkat kesuburannya lebihbaik daripada di bahagian punggung bukit.Keberhasilan agroforestri berbasis pohon salahsatunya didasarkan pada pemilihan jenis. Prinsippemilihan jenis pohon dalam agroforestri adalahketepatan antara lokasi pemapanan dengankarakteristik jenis terpilih serta nilai peruntukanya(Suryanto et al, 2005).

\section{Penelusuran Aspek Ekologi pada Agrosilvopastura}

Pada aspek ekologi, parameter yang disajikan pada makalah review ini adalah laju erosi (tabel 4), total biomassa dan penambatan karbon (tabel 5), serta kapasitas infiltrasi (tabel 6). Data diambil dari penelitian yang dilakukan Abdul-rauf (2004) pada lahan pertanian agroforestri di kawasan penyangga Kabupaten Langkat, Sumatera Utara.

Erosi yang terjadi di lahan agroforestri semuanya berada di bawah erosi yang diperbolehkan, masih dalam taraf tidak membahayakan.Sedangkan erosi yang terjadi pada lahan pertanian monokultur (intensif) merupakan erosi yang membahayakan (jauh lebih besar dari erosi diperbolehkan). 
Tabel 4. Erosi pada tipe agroforestri dan lahan pertanian di kawasan penyangga Kabupaten Langkat pada kemiringan lereng $15-25 \%$.

\begin{tabular}{|l|l|l|}
\hline \multicolumn{1}{|c|}{ Tipe Penggunaan Lahan } & \multicolumn{1}{|c|}{ Erosi aktual (ton/ha/thn) } & Erosi diperbolehkan (ton/ha/thn) \\
\hline Agrosilvicultural & 24.69 & 31,60 \\
Agrosilvopastura & 10,48 & 30,60 \\
Agroaquaforestry & 12,49 & 29,45 \\
Pertanian monokultur & 136,79 & 31,25 \\
\hline
\end{tabular}

Sumber: Abdul-Rauf, 2004

Selanjutnya, di lahan yang sama dilakukan penghitungan total biomassa dan karbon tegakan pada bebarapa subtipe agroforestri di Kawasan Penyangga. Disertai dengan persentase total karbon tanahnya per hektar pada kedalaman $20 \mathrm{~cm}$.

Tabel 5. Biomassa dan total karbon (C) tegakan dan tanah pada beberapa subtipe agroforestry di kawasan penyangga Kab. Langkat.

\begin{tabular}{|c|c|c|c|c|c|c|}
\hline \multirow{2}{*}{\multicolumn{2}{|c|}{$\begin{array}{l}\text { Subtipe Agroforestry dan Jenis Penggunaan Lahan } \\
\text { lainnya }\end{array}$}} & \multirow{2}{*}{$\begin{array}{c}\text { Biomassa } \\
\text { Vegetasi } \\
(\text { ton/ha)*) }\end{array}$} & \multicolumn{2}{|c|}{ C- Vegetasi*) } & \multicolumn{2}{|c|}{ C- Tanah $\left.^{\star *}\right)$} \\
\hline & & & $\%$ & Ton/ha & $\%$ & Ton/ha \\
\hline 1. & $\begin{array}{l}\text { Agrosilvicultura (perkebunan + padi gogo + buah), } \\
\text { hutan rakyat. }\end{array}$ & 24.56 & 36.69 & 9.01 & 7.71 & 129.53 \\
\hline 2. & $\begin{array}{l}\text { Agrosilvicultura (perkebunan + jagung ), hutan } \\
\text { lindung }\end{array}$ & 60.34 & 41.50 & 25.04 & 5.57 & 106.94 \\
\hline 3. & $\begin{array}{l}\text { Agrosilvicultura (perkebunan + cabai + tomat), hutan } \\
\text { lindung }\end{array}$ & 37.59 & 37.54 & 14.11 & 5.17 & 99.26 \\
\hline 4. & Agrosilvicultura (kayu + padi gogo + cabai) & 48.81 & 41.50 & 20.26 & 6.34 & 162.02 \\
\hline 5. & Agrosilvicultura (kayu + kopi + jagung) & 46.73 & 36.76 & 17.18 & 5.61 & 117.88 \\
\hline 6. & Agrosilvicultura (kayu + jahe + kulit manis) & 89.09 & 43.73 & 38.96 & 3.54 & 61.60 \\
\hline 7. & Agrosilvopastura (kayu + karet + durian + rumput) & 85.22 & 45.61 & 38.87 & 6.92 & 150.86 \\
\hline 8. & $\begin{array}{l}\text { Agrosilvopastura (kayu + kulit manis + nangka + } \\
\text { rumput) }\end{array}$ & 29.96 & 41.69 & 12.49 & 4.86 & 97.20 \\
\hline 9. & Agrosilvopastura (kulit manis + petai + rumput) & 197.34 & 45.03 & 88.87 & 7.86 & 138.34 \\
\hline 10. & Pertanian monokultur (jagung) & 12.52 & 22.76 & 2.85 & 5.56 & 121.21 \\
\hline 11. & Pertanian monokultur (padi gogo + cabai) & 9.55 & 22.72 & 2.17 & 3.48 & 64.03 \\
\hline 12. & Hutan alami & 616.40 & 48.69 & 300.15 & 8.22 & 157.82 \\
\hline
\end{tabular}

$\left.{ }^{*}\right)$ total dari semua jenis komponen penyusun dalam subtipe agroforestri

${ }^{* *}$ ) pada tanah lapisan atas (kedalaman $20 \mathrm{~cm}$ )

Sumber: Abdul-Rauf, 2007

Dari Tabel 5 dapat diketahui bahwa biomassa dan karbon total tegakan tertinggi dijumpai pada sistem hutan alami. Sedangkan biomassa dan karbon total tertinggi dari lahan yang telah dibuka (dimanfaatkan) oleh manusia, dijumpai pada subtipe agrosilvopastura dengan struktur atau komponen penyusun utama terdiri dari kulit manis, petai papan serta vegetasi rumput di bawah tegakan tanaman pohonnya, sebesar 88,87 ton per hektar. Total karbon tegakan terendah dijumpai pada sistem penggunaan lahan untuk pertanian monokultur (padi gogo, dan cabai) hanya sebesar 2,17 ton per hektar atau sekitar dari 10,3 kali lebih kecil dibandingkan rerata total karbon tegakan pada sistem agroforestri.

Tabel 5 juga menunjukkan bahwa total karbon tanah yang lebih tinggi selalu diikuti dengan total bioamassa dan karbon tegakan (vegetasi) yang lebih rendah. Total karbon tanah yang lebih tinggi tersebut umumnya dijumpai pada sub tipeagrosilvicultural dibandingkan pada subtipe agrosilvopastura. Sementara total biomassa umumnya lebih tinggi pada tipe agrosilvopastura, kecuali dibandingkan pada sistem hutan alami.

Dibandingkan potensi biomassa dan karbon total pada hutan primer, maka potensi biomassa dan karbon total pada tipe agrosilvopastura dan agrosilvicultura di kawasan penyangga ini masing-masing sekitar 3-6 dan 6-12 kali lebih kecil dari potensi biomassa dan 
karbon total pada hutan primer tersebut. Potensi biomassa hutan primer hasil penelitian Istomo (2002) sebesar 329.18 ton per hektar, sedangkan dari hasil penelitian ini sebesar 616.4 ton perhektar. Namun demikian, potensi biomassa dan karbon total tegakan pada tipe agrosilvopastura dan agrosilvicultura di kawasan penyangga ini, masing-masing sekitar 16,4 dan 7,3 kali lebih besar, bila dibandingkan dengan potensi biomassa dan karbon tegakan yang dijumpai pada sistem pertanian monokultur, yang berarti tipe agrosilvopastura lebih mendekati sistem hutan alami, sedangkan tipe agrosilvicultura lebih mendekati sistem pertanian monokultur bila ditinjau dari potensi biomassa dan total karbon tegakannya.

Parameter selanjutnya, kapasitas infiltrasi tanah pada sistem agroforestri umumnya 1,32,0 kali lebih besar dibandingkan pada sistem pertanian monokultur. Ini berarti kemampuan tanah dalam menyerap air pada sistem agroforestrilebih besar dibandingkan pada sistem pertanian monokultur. Akibat daya serap tanah yang lebih kecil pada sistem pertanian monokultur menyebabkan limpasan permukaan lebih besar, demikian sebaliknya, limpasan permukaan pada system agroforestri lebih kecil karena daya serap tanahnya terhadap air lebih besar (Tabel 6).

Tabel 6. Kapasitas infiltrasi dan limpasan permukaan pada tipe agroforestri dan lahan pertanian di kawasan penyangga Kabupaten Langkat.

\begin{tabular}{|l|l|l|}
\hline \multicolumn{1}{|c|}{ Tipe Penggunaan Lahan } & \multicolumn{1}{|c|}{$\begin{array}{c}\text { Kapasitas Infiltrasi } \\
\text { (cm/jam) }\end{array}$} & $\begin{array}{c}\text { Limpasan Permukaan } \\
\text { (\%/hujan) }\end{array}$ \\
\hline Agrosilvicultur & 65,23 & 35,07 \\
Agrosilvopastura & 42,92 & 39,00 \\
Pertanian monokultur & 33,22 & 45,50 \\
\hline
\end{tabular}

Sumber: Abdul-Rauf (2004)

Kapasitas infiltrasi tanah yang tinggi memungkinkan tanah pada sistem agroforestri dapat menahan air lebih banyak, yang berarti sistem agroforestri ini memiliki peranan lebih besar dalam memitigasi banjir. Dengan selisih antara kapasitas infiltrasi pada tipe agrosilvikultura dengan kapasitas infiltrasi pada pertanian monokultur sebesar $32,01 \mathrm{~cm} / \mathrm{jam}$, berarti pada tipe ini dapat menyerap air $3.201 .000 .000 \mathrm{~cm}^{3}$ atau $3201 \mathrm{~m}^{3}$ atau 3.201 .000 liter lebih banyak dibandingkan pada sistem pertanian monokultur untuk setiap 1 hektar lahan pada setiap 1 jam kejadian hujan. Demikian halnya pada tipe agrosilvopastual yang dapat menyerap air sebesar $970 \mathrm{~m}^{3}$ lebih banyak dibandingkan pada sistem pertanian monokultur untuk setiap hektar lahan pada setiap 1 jam kejadian hujan.

\section{KESIMPULAN}

1. Urutan prioritas alternatif pilihan terpenting untuk membangun pertanian berkelanjutan antara lain penguatan kelembagaan petani,mengembangkan pengkaderan petani / kelompok tani sadar pertanian berkelanjutan, dan peningkatan kegiatandemplot teknologi pertanian berkelanjutan.

2. Berdasarkan komponen penyusunnya terdapattiga sistem agroforestri yang dilakukan olehmasyarakat pada lahan-lahan kritis, yaituberbentuk agrisilvikultur, silvopastura danagrosilvopastura, dimana sistem agroforestriyang ada merupakan sistem agroforestritradisional yang dikelola menurut kondisi dankearifan lokal.

3. Analisis finansialmenunjukkan bahwa secara ekonomi ketigasistem agroforestri di lokasi penelitian layakuntuk dilaksanakan.

3. Sistem agroforestri yang lebih sesuai dan berkesinambungan(pendapatan mencapai kebutuhan hidup layak, lahan tidak terdegradasi dan layak agroteknologi) untuk diterapkan di kawasan penyangga Kabupaten Langkat adalah tipe Agrosilvopastura yang merupakan 
kombinasi pepohonan/tanaman hutan, tanaman pertanian, dan rumput pakan ternak, karena lahan umunya curam sampai sangat curam, solum tanah dangkal dan struktur tanah gembur.

4. Erosi yang terjadi pada lahan agroforestri, terutama agrosilvopastura di kawasan penyangga Kabuaten Langkat tidak membahayakan karena lebih kecil dari erosi yang diperbolehkan ( $<31,6$ ton/ha/thn), sedangkan erosi yang terjadi pada lahan pertanian intensif (monokultur) sekitar 136,79 ton/ha/thn atau 4,4 kali lebih besar dibandingkan erosi yang diperbolehkan.

5. Total biomassa dan karbon tegakan pada sistem agroforestri dengan tipeagrosilvopastura masing-masing sebesar 104.17 dan 46.74 ton per hektar hampir sama dengan total biomassa dan karbon total tegakan pada hutan mangrove Rhizophora apiculata dengan kerapatan 463 pohon per hektar yang masing-masing sebesar 169.46 (biomassa) dan 47.08 (karbon) ton per hektar.

6. Sistem agroforestry dapat berperan dalam memitigasi banjir dibandingkan pada sistem pertanian monokultur untuk setiap hektar lahan pada setiap 1 jam kejadian hujan.

\section{DAFTAR PUSTAKA}

Abdul-Rauf. 2007. Potensi Biomassa Dan Penambatan Karbon Pada Sistem Agroforestri. Makalah Pada Kongres Dan Seminar Nasional Mkti, Cisarua Bogor, 17-18 Desember 2007.

Abdul-Rauf. 2004. Kajian Sistem Dan Optimasi Penggunaan Lahan Agroforestry Di Kawasan Penyangga Taman Nasional Gunung Leuser. Studi Kasus Di Kabupaten Langkat Sumatera Utara. Disertasi Sekolah Pascasarjana Ipb Bogor.

Abdul-Rauf. 2001. Kajian Sosial Ekonomi Sistem Agroforestry Di Kawasan Penyangga Ekosistem Leuser; Studi Kasus Di Kabupaten Langkat Sumatera Utara. Unit Managemen Leuser (Uml), Medan.

Anonim. Pengantar Agroforestri.

Budiasa, I.W. 2011. Pertanian Berkelanjutan : Teori Dan Permodelan. Denpasar : Udayana University Press.

Bukhari dan Indra, G.F. Desain Agroforestry Pada Lahan Kritis (Studi Kasus Di Kecamatan Indrapuri Kabupaten Aceh Besar).Jurnal Perennial, 6(1) : 53-59

Dahuri, R. 1998. Pembangunan Pertanian Berkelanjutan : Dalam Persperktif Ekonomi, Sosial, Dan Ekologi.Agrimedia. Vol. 4 No. 1, Februari, Hal. 5-11.

Hilmi, E. 2003. Model pendugaan kandungan karbon pada pohon kelompok jenis Rhizopora Sp dan Brugueira Spp. dalam tegakan hutan mangrove. Studi Kasus di Kabupaten Indragiri Hilir Riau.Disertasi PPS IPB Bogor.

Idjudin, A.A., Y. Soelaeman, Dan A.Abdurrahman. 2003. Keragaan Dan Dampak Penerapan Sistem Usahatani Konservasi Terhadap Tingkat Produktivitas Lahan Perbukitan Yogyakarta. Jurnal Litbang Pertanian 22(2),Hal. 49-56.

Ma'ruf, A. Mardu, R. Andayani, N. 2014. Respon Bibit Mucuna bracteata Terhadap Intensitas Sinar Matahari. Institut Pertanian Stiper Yogyakarta

Ma'ruf, A. Putra, E, T, S. Waluyo, S. 2016. Pengaruh Pyraclostrobin Terhadap Aktivitas Fisiologis, Produktivitas, Dan Kualitas Pucuk Teh Assamica (camellia Sinensis Var. Assamica (mast.) Kitamura) Pada Musim Kemarau. Universitas Gadjah Mada

Ma'ruf, A. Sinaga, A. 2016. Pengaruh Pemanasan Global Terhadap Beberapa Tanaman C3 Di Indonesia. Bernas

Ma'ruf, A. Putra, E, T, S. Waluyo, S. 2016. Effect Of Pyraclostrobin Concentration On Quality Shoots Of Assamica Tea. Agricultura 
Ma'ruf, A. 2016. Respon Beberapa Kultivar Tanaman Pangan Terhadap Salinitas. Bernas

Ma'ruf, A. 2016. Pengaruh Pemanasan Global Terhadap Beberapa Tanaman C3 Di Indonesia. Bernas

Ma'ruf, A. Zulia, C. Safruddin. 2017. Rice Estate Development As State Owned Enterprises (SOEs) To Self Supporting For Food. European Academic Research

Ma'ruf, A. Zulia, C. Safruddin. 2017. Legume Cover Crop di Perkebunan Kelapa Sawit. Forum Pertanian Asahan

Mustofa, A.S dan Tony, D dan Hadi, S.A dan Nurheni, W. Klasifikasi Dan Pola Kombinasi Komponen Agroforestri. World Agroforestry Centre (Icraf)

Purwanto Dan S. Andy Cahyono, 2012. Identifikasi Kerentanan Sosial Ekonomi kelembagaan Untuk PengelolaanDas Tulis (Dataran Tinggi Dieng). Prosiding Seminar Nasional Pengelolaan Sumberdaya Alam DanLingkungan, Semarang, 11 September 2012.

Sasongko, Putra dan Purwanto dan Kismartini. 2013.Perencanaan Pertanian Berkelanjutan Di Kecamatan Selo. Prosiding Seminar Nasional Pengelolaan Sumberdaya Alam Dan Lingkungan

Sajogyo, 1977. Garis Miskin dan Kebutuhan Minimum Pangan. Lembaga Penelitian Sosiologi Pedesaan (LPSP) IPB Bogor.

Sinaga, A. Ma'ruf, A. 2016. Tanggapan Hasil Pertumbuhan Tanaman Jagung Akibat Pemberian Pupuk Urea, SP-36, dan KCl. Bernas

Wiyanto, G. Ma'ruf, A. Puspaningrum, E, S. 2014. Panen Rupiah dari Ladang Jahe. Bhafana Publishing 